\title{
Mobilizing Youth for Participation in Nigerian Agricultural Transformation Agenda: A Grassroots' Approach.
}

\author{
Lyocks, J. S. ${ }^{1}$, Lyocks S.W.J. ${ }^{2}$, and Kagbu J. H. ${ }^{3}$. \\ ${ }^{1}$ Department of Agricultural Economics and Rural Sociology \\ Faculty of Agriculture, Ahmadu Bello University, Zaria \\ ${ }^{2}$ Samaru College of Agriculture \\ Division of Agricultural Colleges, \\ Ahmadu Bello University, Zaria \\ ${ }^{3}$ Department of Agricultural Science, \\ School of Vocational and Technical Education, \\ Federal College of Education Technical, Bichi, Kano State \\ Corresponding Author: - Lyocks, J.S. Email: jillyocks@yahoo.com \\ Phone No; 08026027240
}

\begin{abstract}
The study examined the best approach to mobilize youth to participate in the Agricultural Transformation Agenda (ATA) of Nigeria. The study was conducted in two Agricultural Development Project zones of Kaduna State. Data for the study were collected using structured questionnaire, which was administered to 121 youths and analysed using descriptive statistics. Majority (88\%) of the youth was interested in agriculture and $93 \%$ willing to participate in Agricultural Transformation Agenda. About 68\% of the youths perceived that the agricultural transformation would create employment and reduce poverty among youths. Most of the respondents suggested that training and skills development centres should be established and their needs should be assessed before launching any agricultural programmes like ATA. A large number (92\%) of the youths indicated readiness to participate in the transformation agenda. Therefore, it is recommended that the needs of the youth be assessed before mobilizing them for agricultural transformation agenda.
\end{abstract}

\section{Introduction}

Young people everywhere are key agents for social change, economic development and technological innovation. They have aspirations and want to participate fully in the development of their societies. Youths have the potential to overcome some of the major constraints to expanding agricultural production in the country because they are often more open to new ideas and practices than adult farmers. Encouraging young people back into agriculture would be an appropriate way of harnessing youths' potentials. Governments are very aware of the importance of engaging young people in agriculture, especially given the average rate of unemployment in sub-Sahara Africa of over $20 \%$ and the unemployment rate in Nigeria was last reported at 23.9 percent in 2011. The National Bureau of Statistics (NBS) has put the figure of unemployed Nigerians in the first half of 2012 at 23.9 per cent, up from 21.1 per cent in 2010 and 19.7 per cent in 2009(Osalor, 2012). In 2006, African heads of state signed the African Youth Charter, which recognises the right of young people to be free from hunger and calls on governments to take measures to enhance the attractiveness of rural areas to young people; train them to take up agricultural, mineral, commercial and industrial production using contemporary systems and promote the benefits of new ICTs to gain access to markets (AYC, 2006). Through the Charter, governments also agreed to provide land as grants and access to credit and facilitate the participation of young people in the design and implementation of national development policies and poverty reduction strategies. 
For youth to keep practicing farming, it is necessary that agriculture becomes intellectually satisfying and economically rewarding (Anon., 2011). This was the motive for the Agricultural Transformation Agenda (ATA) in Nigeria.

\section{Statement of problem}

One of the major setbacks of Nigerian agricultural development programmes is attributed to the inability of the federal government to integrate youths into the mainstream of the numerous agricultural development programmes implemented over the years (ljere, 1992). The agriculture extension services are still ignoring youths as dynamic partners of extension work. For a country to attain economic stability the agricultural sector must be vibrant and the youths encouraged to imbibe farming as a noble profession (Ojediran, 1997). Nigeria needs a roadmap to sustainable food production and security. As a result it is necessary to encourage increased food production in the country by increasing the number of producers and the level of productivity. The youth population is strategic to the success of these efforts to boost food production. Therefore, farming and agri-businesses must be made attractive for young entrepreneurs. The poor image of persons involved in agriculture needs to be changed and young people are the ideal catalysts for such change given their greater propensity and willingness to adopt new ideas, concepts and technology which are all critical to changing the way agriculture is practiced and perceived. One of the things missing in agriculture today is imagination. Today's generation of farmers, teachers, agricultural scientists, policy makers and even media specialists, have collectively failed to trigger youths' imagination.

Nigerian Agricultural Transformation Agenda anchored by the Ministry of Agriculture promises the creation of over 3.5 million jobs to young people and women across the country, a situation that would definitely improve the lot of Nigerians. If the programme is supported by the highest level of government through the states and local governments and all other players involved, the nation, would soon be feeding itself as well as feeding most of West African nations. These can be achieved only if the youth are adequately mobilized and involved in planning, designing and implementing all youth oriented programmes. A major bottle neck of agricultural programme in Nigeria has always been due to poor implementation. Such poorly implemented programmes have always left wide gaps between expected and actual results obtained.

This paper exams youths perception of agriculture, ATA and their level of preparedness and how they should be involved in ATA using a grass root approach. This involves sensitizing youths, assessing their needs; and solicits the best approach to ATA implementation encouraging youth forum formation and establishes linkages to solve the agricultural image problem among the youths. 


\section{Methodology}

The study was carried out in three local government areas (LGAs) each of zone I (Maigana) and zone 2(Samaru Kataf) of Kaduna State Agricultural Development Projects. A sample size of 121 respondents was used for this study.

A multi staged sampling technique was used to select respondents involved in this study. Zones I and II were purposively selected to capture the social, economic and climatic variability of the state. In stage two, Sabon gari, Giwa and Kudan LGAs from zone I and Jema'a, Kachia, Zangon Kataf from zone II were also purposively selected to include at least one rural and one urban based LGAs in the study area. The last stage involved a proportionate random sampling of ten youths each from two randomly selected wards of the LGAs. Data were collected through the use of structured questionnaire comprised of thirty five information items. To ascertain perceived benefits for youth involvement in agriculture, five item statements were presented and the acceptance or otherwise to youths were assessed based on a five point likert-scale of strongly agree, agree, undecided, disagree and strongly disagree. Statistical tools used to analyse the data include descriptive statistics correlation and chi-square.

\section{Results and Discussion}

\section{Socio-economic Characteristics}

Table 1 Shows that majority (75.2\%) of the respondents was males and $65.3 \%$ were between ages 23- 27 years. This aligns with findings of Aphunu and Atoma (2010) that had $73.9 \%$ within ages 21 and 25years in their study. Most $(73.6 \%)$ were not married. Students made $61.2 \%$ of the sampled population and $61.2 \%$ were in tertiary institutions. Education is important in creating positive mental attitude towards adoption of modern farming innovations (Benor et al., 1997). Table 1 also shows that $51 \%$ of the respondents first had agriculture science lessons while in the primary school, $75.2 \%$ liked the agriculture then but now interest in agriculture among the respondents has increased to $87.6 \%$. This suggests that more and more youth are interested in agriculture, hence youth full participation in ATA is guaranteed because youth generally have greater knowledge acquisition propensity (Jibowo and Sotomi, 1996) and hence they are eager to learn, receptive to new ideas, looking for ways to be productive and searching for avenues to direct their energies. A worrisome situation observed in Table 1 was the very low (38\%) membership of youths to agricultural organizations. Youth organizations the world over are vital organs for mobilizing youth into agricultural activities. This needs to be encouraged to enhance attainment of ATA goals and objectives. 
Table 1: Socioeconomic Characteristics of Respondents

\begin{tabular}{|c|c|c|}
\hline Characteristic & Units & Percentage $(n=121)$ \\
\hline \multirow[t]{2}{*}{ Gender } & Male & 75.2 \\
\hline & Female & 24.8 \\
\hline \multirow[t]{5}{*}{ Age } & $18-22$ & 20.7 \\
\hline & $23-27$ & 44.6 \\
\hline & $28-32$ & 24.0 \\
\hline & $33-37$ & 9.1 \\
\hline & $38-42$ & 1.7 \\
\hline \multirow[t]{2}{*}{ Marital Status } & Married & 26.4 \\
\hline & Single & 73.6 \\
\hline \multirow[t]{5}{*}{ Highest Education Attained } & Primary & 0.8 \\
\hline & Secondary & 21.3 \\
\hline & Tertiary & 61.2 \\
\hline & Postgraduate & 14.9 \\
\hline & None & 1.7 \\
\hline \multirow[t]{5}{*}{ Occupation } & Civil Servant & 19.0 \\
\hline & Farmer & 7.4 \\
\hline & Student & 61.2 \\
\hline & Daily Worker & 4.1 \\
\hline & Unemployed & 8.3 \\
\hline \multirow[t]{4}{*}{ Attitude to Agriculture } & Like it & 75.2 \\
\hline & Do not like it & 4.1 \\
\hline & Neutral & 17.4 \\
\hline & Forced to like it & 3.3 \\
\hline $\begin{array}{l}\text { Youths' Perceived benefits of } \\
\text { Engagement youth in }\end{array}$ & $\begin{array}{l}\text { Ready Source of } \\
\text { farm labour }\end{array}$ & 1.7 \\
\hline \multirow[t]{6}{*}{ Agriculture } & $\begin{array}{l}\text { Means of } \\
\text { reducing } \\
\text { unemployment }\end{array}$ & 56.2 \\
\hline & $\begin{array}{l}\text { Channel of } \\
\text { introducing new } \\
\text { Agric }\end{array}$ & 11.6 \\
\hline & Increasing & 22.3 \\
\hline & Agricultural & \\
\hline & Productivity & \\
\hline & $\begin{array}{l}\text { Income } \\
\text { generation }\end{array}$ & 8.3 \\
\hline \multirow[t]{2}{*}{ Membership of agricultural Association } & Yes & 38 \\
\hline & No & 62 \\
\hline Desiring to Participate & Yes & 92.6 \\
\hline in ATA? & No & 7.4 \\
\hline
\end{tabular}

\section{Constraints to youth involvement in agriculture}

This study identified factors that have hitherto hindered youth participation in agriculture. Most prominent among these constraints was inadequate incentives (39.7\%). Agriculture is not featured prominently in the media and is rarely glamorous when it is. Working with the media to provide more interesting portrayals of agricultural careers is important, as is working with ICTs and social media to reach a broader audience.

Discussions with youth revealed that the rural areas have not been made attractive enough to restrain the youth from migrating to urban cities to look for other jobs (other than 
agriculture). WHO (2013) reported that currently around the world we are living in an era where rapid urbanization has led to a decline in rural population and for the first time ever the majority of the world's population lives in a city. Lack of incentives could include inadequate fund available for youths interested in agriculture reported by Umeh and Odom (2011).These partly explain why we have decline in the number of youth in agriculture.

Inadequate training and extension services $(28.9 \%)$ ranked second on the constraint list. According to UNESC (2003) level of illiteracy in Nigeria was $31.9 \%$. This suggests that even the few youth that are involved in farming were traditional farmers since there are incentive and no training for skills acquisition in agriculture.

Another constraint (Table 2) was inadequate infrastructure (21.5\%). Llanto, (2011) hypothesized that rural infrastructure raise agricultural productivity, which in turn induces growth in the rural areas and brings about higher agricultural wages and improved opportunities for nonfarm labour He asserted that one of the factors behind the successful integration and rapid economic growth of East Asian economies into the global economy was the high quality of infrastructure.

Table 2: Major constraints to youth involvement in agriculture

\begin{tabular}{lcc}
\hline Constraints & Percentage & Ranking \\
\hline Inadequate Incentives & 39.7 & 1 \\
Inadequate Training and Extension Services & 28.9 & 2 \\
Inadequate, poor conditions and inefficient & 21.5 & 3 \\
infrastructure & & \\
Insufficient Land & 4.1 & 4 \\
Others & 5.8 & 5 \\
Total & 100 & \\
\hline
\end{tabular}

\section{Grass root mobilization of youth for participation in ATA.}

Table 3 revealed the result of young people views on key issues they want the government to address to make ATA implementation successful. This approach was adopted to give the youth a chance to air their views, share their experiences on agriculture and how they would want to be involved in ATA. It was established from the needs assessment of the youth that the most popular way to mobilize the youth for agriculture (ATA) is to establish training and skills acquisition centres (51.2\%). This desire might have risen from the assertion that many young people have little or no skills and are excluded from productive economic and social life. Farm Africa (2011) reported that most pupils (in Kenya) lacked access to training and education on farming and therefore were not being encouraged to perceive agriculture as a future career. More so, the skills and competencies of agricultural graduates do not meet the needs of today's agricultural sector. It therefore suggests that a curriculum reform in tertiary level agricultural education is required to meet the demands of the labour sector, with particular attention to agribusiness and entrepreneurship, where many youth demonstrate an interest. In this study (Table 4) most $82(67.8 \%)$ of the respondents re-echoed the need to make agricultural science curriculum to be practical oriented. The training subjects should be selected based on the needs of the members and that of the community through participatory decision-making; the training should be conducted by a "learning by doing" method. Sharing of knowledge and skills among the participants provide the basis for mutual learning. Japan does not only incorporate agriculture education in the curricula of secondary schools, junior colleges and universities, but it also administers training programmes in farmers' colleges and short-term programs organized by the district agriculture extension workers (FAO, 20005). Youth require a range of skills and competencies beyond their technical discipline, particularly those 'soft' skills such as communication, leadership and business skills. 
Reform of the agricultural curriculum must be a fully inclusive process which involves a wide range of stakeholders including youth. With high unemployment rates globally and the lack of interest in traditional agricultural pursuits, a greater focus on entrepreneurship in agriculture is emerging. Entrepreneurship has the potential to contribute to the rejuvenation of the industry, creating more employment opportunities, increasing the potential for profit and moving away from the perception of agriculture as a low prestige career.

Youths' access to agricultural loan is important (key) to their participation in ATA. This is more a less an indication of government commitment to the programme and will attract more youth to agriculture. To these effects, the government to create an enabling environment for youth to enter into the agricultural sector, a supportive policy environment focused on youth is required. Access to land and finance is a barrier for many, which is essential for farming and agricultural entrepreneurship. The need for access to land was recorded by $62.8 \%$ of the youth while almost an equal number $(62 \%)$ mentioned the credit needs in the youth need led analysis in Table 4.

\section{Table 3: How to mobilize youth for participation in ATA}

\begin{tabular}{llc}
\hline S/No. & Options & Percentage \\
\hline 1 & Establish youths training and skills acquisition centres & 51.2 \\
2 & Give agricultural loans to youths & 31.4 \\
3 & $\begin{array}{l}\text { Promote young farmers associations through internet } \\
\text { linkages }\end{array}$ & 12.4 \\
4 & Establish farm settlements & 5.0 \\
\hline
\end{tabular}

Rural youth encounter economic and physical barriers that prevent them from receiving adequate care, services, or resources necessary for healthy development. Grants would break down barriers to participation, especially for rural youth; enhance opportunities for youth involvement in policy and decision-making; create safe and inviting environments for youth activities; and improve access to information and technology.

Other areas that the youths' needs assessments revealed as motivation to attracting youths' participation in ATA were to give youth a voice in the society and let them be heard $(58.7 \%)$. This is crucial for youths' involvement in agriculture as it gives them a sense of belonging to the society and to bring out the voice of the youth on several issues related to capacity development. Efforts must be made to link young agricultural professionals together, provide information, show the many opportunities existing in agricultural development and share the success stories of young role models and encourage young people to become more involved in agriculture. Youth should be encouraged to take advantage of an ICT-savvy generation to share and exchange ideas and information. ICTs have a great role to play in agricultural development and food security, and youth have a great role to play in ICTs. 
Table 4: How youths can be mobilized for AT

\begin{tabular}{|c|c|c|c|c|c|c|}
\hline \multirow[t]{2}{*}{ Youths Need-led Approach } & 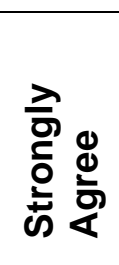 & 巡 & $\begin{array}{l}\text { 엉 } \\
\text { 응 } \\
\frac{d}{0} \\
\text { c }\end{array}$ & 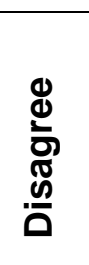 & 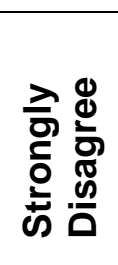 & \multirow[t]{2}{*}{ 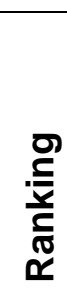 } \\
\hline & $\%$ & $\%$ & $\%$ & $\%$ & $\%$ & \\
\hline $\begin{array}{l}\text { Make Agricultural } \\
\text { curriculum more } \\
\text { oriented. }\end{array}$ & 67.8 & 26.4 & 5.8 & 0 & 0 & 1 \\
\hline Provide Land for Agriculture. & 62.8 & 27.3 & 9.9 & 0 & 0 & 2 \\
\hline $\begin{array}{l}\text { Provide grants/credit facilities } \\
\text { to youths interested in } \\
\text { agriculture. }\end{array}$ & 62.0 & 32.2 & 5.8 & 0 & 0 & 3 \\
\hline $\begin{array}{l}\text { Train youths to take up } \\
\text { agriculture as a business. }\end{array}$ & 61.2 & 29.8 & 5.8 & 3.3 & 0 & 4 \\
\hline $\begin{array}{l}\text { Give Youth a voice in the } \\
\text { society and let them be heard. }\end{array}$ & 58.7 & 32.2 & 5.8 & 3.3 & 0 & 5 \\
\hline $\begin{array}{l}\text { Recognize Youths as } \\
\text { stakeholders in agriculture. }\end{array}$ & 54.5 & 36.4 & 5.8 & 2.5 & 0.8 & 6 \\
\hline $\begin{array}{l}\text { Make rural areas attractive to } \\
\text { youth. }\end{array}$ & 54.5 & 34.7 & 7.4 & 0.8 & 0 & 7 \\
\hline $\begin{array}{l}\text { Organise Agricultural } \\
\text { Competition among youth and } \\
\text { reward good results. }\end{array}$ & 47.9 & 41.3 & 8.3 & 1.7 & 0.8 & 8 \\
\hline $\begin{array}{l}\text { Assess youth needs and } \\
\text { encourage agricultural group } \\
\text { formation for agricultural } \\
\text { programmes. }\end{array}$ & 43.0 & 43.0 & 7.4 & 5.0 & 1.7 & 9 \\
\hline $\begin{array}{l}\text { Facilitate participation of } \\
\text { youth in design and } \\
\text { implementation of Agricultural } \\
\text { Development Programmes. }\end{array}$ & 42.1 & 47.1 & 9.1 & 0.8 & 0.8 & 10 \\
\hline
\end{tabular}




\section{Areas of interest and careers}

Crop Farming (31.4\%), Poultry Production (28.1\%) and Crop/livestock marketing (17.4\%) were identified as the common areas of interest by the youth (Table 5). The choices made the youth reflected the agricultural system of the area where crop production is predominant while fish farming is not so popular especially in the rural areas.

Table 5: Areas of interest of youth in agriculture

\begin{tabular}{llc}
\hline S/No & Areas of interest/career & Percentage \\
\hline 1 & Crop farming & 31.4 \\
2 & Poultry production & 28.1 \\
3 & Crop/livestock marketing & 17.4 \\
4 & Livestock farming & 10.7 \\
5 & Crop processing & 9.1 \\
6 & Fish farming & 3.3 \\
\hline
\end{tabular}

\section{Conclusion}

Agricultural transformational agenda focuses on changing youth attitudes. Youth organizations in Agriculture are formed purposely to enhance the cognitive affective and psycho motive development of the youth. This can encourage them to take up farming as a profession or a part time job. Participation in youth agriculture organizations enhances the development of good leadership traits in youths. The overall effect will lead to the development of a good citizen and nation. All hands must be put on deck in making the agricultural revolution a reality. We must all remember that our (in) actions all have future and global consequences. It is up to the Nigerian youth of today to embrace agriculture to ensure that the legacy we leave behind for our children is better than the one we met.

\section{Recommendation}

General recommendations for increasing youth involvement in agriculture by appropriately mobilizing youth to participate in the government agricultural transformation agenda include:

1. Youths' needs, experiences and views should be assessed and incorporated into ATA implementation strategies.

2. Youth should be made to access improved training and capacity development such as creating training and skills acquisition centres in all wards in the local government areas in addition to improved training at the primary and secondary school levels and linking school agricultural operations with general curriculum;

3. More opportunities for on farm training for youth and enterprise development training particularly in value added activities such as food processing and packaging should be made available. This will facilitate access to and encourage the use of appropriate technology for transformation in agriculture.

4. Adequate policies and legislation for improved and easier access to resources such as land, capital, technology and information would help the youths develop the adequate interest in youths to be involved in agricultural activities.

5. Providing motivation and improving the image of agriculture by provide infrastructures in the rural areas. 


\section{References}

Adekunle, O.A., Oladipo, L.L., Adisa R.S. F.O., Fatoye, A.D., (2009). Constraints to youth's involvement in agricultural production in Kwara State, Nigeria. Nigeria. Journal of Agricultural Extension, Vol. 13(1), pp 102-108.

African Youth Charter (2006). African Youth Charter, A Framework defining Africa's Youth Agenda! http://africa-youth.org/charter.

Anonymous, (2011). Training youth in agriculture biggest challenge. The Indian Express.

Anonymous (2013) Make agriculture attractive to youth. Actualité en Ligne - AfriqueJet

Économie - Politique - Sport - Santé - Société - Technologies - Culture -

Environnement - Sciences - Energie - Agriculture - Sécurité.

http://www.afriquejet.com/news/4336-make-agriculture-attractive-to-youth.html. Retrieved August 16, 2013

Aphunu A. and Atoma C.N. (2010). Rural youths' involvement in agricultural production in Delta Central Agricultural Zone: Challenges to agricultural extension development in Delta State. Journal of Agricultural Extension, Vol. 14(2), pp 46-55.

Benor, D., Harrison, J.Q. and Baxter, M. (1997). Agricultural Extension: The Training and Visit system. Washington, D.C. 2 the World Bank.

Farm Africa (2011) Engaging Youth in Agriculture - The Key to a Food Secure Future? Farm -first. http://www.farmingfirst.org/tag/farm-africa/ Retrieved August 2, 2013

Food and Agriculture Organization (2005) Improving Youth Organizations in Asia: Lessons from Three Asian Case Studies. Food and Agriculture Organization of the United Nations Regional Office for Asia and the Pacific Bangkok, Thailand.

Ifenkwe, G.E. (2012) Mobilizing and Empowering Youths for Sustainable Community and Rural Development in Nigeria. International Journal of Academic Research in Progressive Education and Development, 1(2):144-152.

ljere, M. O. (1992). Leading Issues in Rural Development. Enugu. ACENA Publisher Ltd.

International Labour Organization (2012) Unemployment rates. global food for thought. Typepad.com/global-food-for-thogth/2013/02/commentary-engaging-youth-in agriculture-investing-in-our-future. html\#_ftn1

Jibowo, A.A. and Sotomi, A.O. (1996). The Youths in Sustainable Rural Development. A study of Youth Programmes in Odeda Local Government Area of Ogun State. In: Ladele, A.A. et al (eds). Policy Advocacy Role in Agricultural and Rural Transformation in Nigeria. Proceedings, $17^{\text {th }}$ Annual Congress of the Nigerian Rural Sociological Association (NRSA), NRCRI, Umudike, $19^{\text {th }}-22^{\text {nd }}$ August. Pp. 54-57

Llanto, G.M. (2011). Does poor rural infrastructure constrain agricultural productivity? Regional windows. East \& Southeast Asia http://cloud2.gdnet.org/ research papers/Does\%20poor\%20rural\%20infrastructure\%2 0constrain\%20agricultural\%20productivity? Retrieved August 22, 2013

Newsroom (2011). Farmers need help. Farming news daily. http://www.farmingnewsdaily.co.uk/news/040711/farmers need help.aspx. Retrieved August 8, 2013 
Ojediran, B. (1997). Battling the risk of managing agriculture, Lagos: The Guardian Daily Newspaper, April, 10th.

Osalor, P (2012). Youth Restiveness and unemployment in Nigeria: The way out part 1. The Vanguard. http://www.vanguardngr.com/2012/12/youth-restiveness-andunemployment-in-nigeria-the-way-out-part-1-3/. Retrieved August 1, 2013

Panday Dinesh (2013) "Youth and agriculture: It's up to us", youth and agriculture, Farming Matters, YPARD Reports June 2013, p.27. Article available on agriculture network.org website.

Umeh, G.N. and Odom (2011). Role and constraints of youth associations in agricultural and rural development: Evidence from Aguata L.G.A of Anambra State, Nigeria. World Journal of Agricultural Science 7 (5): pp 515-519

UNESCO (2003) World Development Indicators database; UNESCO; UNESCO UIS Data UNESCO Institute for Statistics; The Geography Zone; Household survey data, net enrolment data. http://www.nationmaster.com/country/ni-nigeria/edu-education

United State Department of Agriculture National Institute of Food and Agriculture (2013). Rural youth development grants. http://www.ehow.com/info 7941287 rural-youthdevelopment-grants.html\#ixzz2bT6Zm2K9

World Health Organization (2013). Engaging youth in agriculture-The key to a food security future? Farm First. Posted in: Blog, education and training, food and nutrition security, Kenya, Principle 2: share knowledge, sustainable Agriculture, Tanzania, United Kingdom. Retrieved August 1, 2013 